\title{
PHYTIC ACID CONTENT AND DIGESTIBILITY OF COCONUT RESIDUES DERIVED-PROTEINS AFTER SOLID-STATE FERMENTATION BY Aspergillus awamori
}

\author{
AIZAT MOHD-RAZALI ${ }^{1}$, MASDUKI MOHAMAD MORNI ${ }^{2}$, MARIAM TAIB ${ }^{3}$ \\ and AZIZ AHMAD $2,3^{*}$ \\ ${ }^{1}$ Faculty of Engineering Science and Technology, \\ Infrastructure University of Kuala Lumpur, \\ 43000 Kajang, Selangor, Malaysia \\ ${ }^{2}$ Centre for Fundamental and Continuing Education, \\ Universiti Malaysia Terengganu, 21030 Kuala Nerus, Terengganu, Malaysia \\ ${ }^{3}$ Faculty of Science and Marine Environment, Universiti Malaysia Terengganu, \\ 21030 Kuala Nerus, Terengganu, Malaysia \\ ${ }^{*} E$-mail:aaziz@umt.edu.my
}

Accepted 16 October 2020, Published online 25 December 2020

\begin{abstract}
The growing industry of aquaculture is in demand of alternative protein sources as fish feeds. An adequate amount of digestible protein and the presence of anti-nutritional such as phytic acid factors are limiting factors in feed formulations. One alternative source of protein for fish feeds is fermented coconut residues. However, the phytic acid content, an anti-nutrient compound produced during the bioconversion or fermentation process of agriculture waste has not yet been determined. Therefore, the objective of the present study was to determine the phytic acid content and protein digestibility of coconut residues after solid-state fermentation (SSF) by Aspergillus awamori. Samples from three optimized fermentation conditions were analyzed for soluble proteins, phytic acid contents, and in-vitro digestibility activity by trypsin and pepsin. Results showed that phytic acid content in all samples were lower than $0.1 \mathrm{mg} / \mathrm{g}$ dry wt. of the sample after seven days of fermentation. The protein digestibility by trypsin (ranging from $36.54 \pm 4.22$ to $43.22 \pm 2.46 \%$ ) was higher than pepsin, where it fell within the percentage required for fish feed formulation. The findings suggested that fermented coconut residues are a highly potential alternative source of protein for fish feed formulation.
\end{abstract}

Key words: Fish feed, protein, phytic acid, in vitro protein digestibility

\section{INTRODUCTION}

The expansion of the aquaculture industry especially in Asia has induced tremendous demand for aqua-feed, where the production rate has exceeded $30 \%$ annually. The cost of feed could rise to $60 \%$ of the total cost for industry and the demand is continuous. Proteins appeared as the most expensive nutrients in feed, which subsequently caused increasing costs in feed production, growth of fishes, industrial maintenance, and finally the price of fishes (Gaylord \& Barrows et al., 2009). The protein requirement is species-specific with regards to herbivorous, omnivorous, and carnivorous fishes. To compute an adequate amount of protein in feed,

* To whom correspondence should be addressed. the content of essential amino acids must meet the requirements of the species to be fed. Alternative protein sources are strongly recommended to sustain the growing industry of aquaculture to reduce the cost of feeding. Protein in feed depends on its availability, digestibility, the content of amino acids and nutrients, anti-nutritional factors, and significantly the cost of production and species (ElSayed et al., 1999; Gilani et al., 2005; Abdelnour et al., 2018).

Over the years, plant-derived feeds such as palm kernel cake and coconut residues (Syahri et al., 2016; Farizaldi et al., 2017), pineapple pulp and cassava (de Lima et al., 2012; Duy \& Khang, 2017) have been introduced to minimize the cost of feeds. The recycling of the waste matters was also proven to be useful in reducing the production cost 
up to $20 \%$ off the feed and feeding cost for the industry. The uses of microbes particularly fungi in converting plant carbohydrates as a substrate with supplementation of salt to protein is a useful approach (Ramachandran et al., 2004). Coconut residues in general contain soluble sugar, protein, starch, lipids, and traces of nitrogen (Ramachandran et al., 2004). The high amount of carbohydrate fiber instead of protein (Francis et al., 2001) has triggered many studies to improve its nutritional value. Additionally, fermented copra meals have been tested on grouper (Mamauag et al., 2019). The fungus Aspergillus is known as one of the fungi most commonly used in improving the protein content of cassava and sugar cane bagasse (MooYoung et al., 2000). Aspergillus awamori is commonly known for the awamori process, which is the conversion of starch to citric acid. During the fermentation process, the starch digestion enzymes are among the type of soluble proteins that are secreted onto the substrate. These secreted proteins normally identified as amylase and starchdisbranching enzymes, have been utilized in the diet of broiler chickens (Morgado et al., 2016) and laying hens (Saleh et al., 2017). In our previous study, the optimum condition for solid-state fermentation of coconut residues by A. awamori has been designated (Mohd-Razali et al., 2019). Nonetheless, the accumulation of anti-nutrient content such as phytic acid and protein digestibility, which is crucial in feed formulation has not been reported. Therefore, the objective of the current study was to determine the phytic acid and soluble protein contents of coconut residues after selected fermentation conditions (Table 1), and the protein digestibility activity by trypsin and pepsin.

\section{MATERIALS AND METHODS}

\section{Fermentation conditions}

Sample preparation and fermentation procedures were performed according to the method previously described by Mohd-Razali et al. (2019). Based on the previous study, three solid-state fermentation (SSF) conditions (Table 1) were used. Sampling activities were carried out every two day-interval, five days after fungal inoculation (DAI) until 13 DAI. Upon harvest, the total soluble protein and phytic acid contents were analyzed. Also, the protein digestibility rate (\%) by trypsin and pepsin were determined on samples that encompassed the highest protein content, which was nine or eleven DAI (Table 2), respectively. Triplicates were applied for each condition.

\section{Soluble protein and phytic acid contents}

The soluble protein was extracted using the mild-acid extraction method as described by Pickardt et al. (2009) with slight modification. Three grams of samples were mild-acid extracted in $2.0 \mathrm{~mL}$ McIlvaine buffer ( $\mathrm{pH} 4.0$ ). The mixture was centrifuged (Eppendorf, USA) at $7000 \times g$ for $30 \mathrm{~min}$ at $4{ }^{\circ} \mathrm{C}$. The total protein content in the supernatant was determined using the Bradford method (1976) at wavelength $595 \mathrm{~nm}$ based on the standard curve of the bovine serum albumin (BSA) in the range of 2.0 to $10.0 \mu \mathrm{g} / \mathrm{mL}$.

The phytic acid content was determined according to Sadasivam and Manickam (1996). Five hundred $\mathrm{mg}$ of dried and finely pounded sample was extracted in $50 \mathrm{~mL}$ of $3 \%(\mathrm{w} / \mathrm{v})$ trichloroacetic acid (TCA), with continuous shaking for $30 \mathrm{~min}$. The mixture was then centrifuged at $3000 \times g$ for $10 \mathrm{~min}$. The supernatant $(10 \mathrm{~mL})$ was mixed with $4.0 \mathrm{~mL}$ of

Table 1. The solid-state fermentation conditions of the coconut residue samples

\begin{tabular}{lccc}
\hline \multirow{2}{*}{ Conditions } & \multicolumn{3}{c}{ Sample } \\
\cline { 2 - 4 } & A & B & C \\
\hline Size of Inoculum $(\%)$ & 10 & 20 & 30 \\
Temperature of Incubation $\left(0^{\circ} \mathrm{C}\right)$ & 30 & 30 & 40 \\
Salt Level (x times) & 3 & 2 & 3 \\
\hline
\end{tabular}

Table 2. The total soluble protein content in three selected solid-state fermentation conditions (Sample A, Sample B, and Sample C) at different days of fungal inoculation (DAI). $(n=3$; mean $\pm S E)$. A similar letter in the same column indicates no significant difference, $p<0.05$ by Tukey test)

\begin{tabular}{cccc}
\hline \multirow{2}{*}{$\begin{array}{l}\text { Day after fungal } \\
\text { inoculation (DAI) }\end{array}$} & \multicolumn{3}{c}{$\begin{array}{c}\text { Total soluble protein content in fermented coconut residue } \\
\text { (mg/g dry wt. sample) }\end{array}$} \\
\cline { 2 - 4 } & Sample A & Sample B & Sample C \\
\hline 5 & $23.25 \pm 0.93^{\mathrm{c}}$ & $26.51 \pm 2.32^{\mathrm{b}}$ & $35.81 \pm 1.40^{\mathrm{c}}$ \\
7 & $30.25 \pm 2.32^{\mathrm{b}}$ & $30.70 \pm 2.32^{\mathrm{a}}$ & $35.81 \pm 1.86^{\mathrm{c}}$ \\
9 & $39.41 \pm 2.10^{\mathrm{a}}$ & $32.10 \pm 0.93^{\mathrm{a}}$ & $37.67 \pm 0.46^{\mathrm{c}}$ \\
11 & $37.67 \pm 1.40^{\mathrm{a}}$ & $36.94 \pm 3.28^{\mathrm{a}}$ & $51.21 \pm 0.67^{\mathrm{a}}$ \\
13 & $36.27 \pm 1.39^{\mathrm{a}}$ & $33.48 \pm 3.25^{\mathrm{a}}$ & $45.58 \pm 1.39^{\mathrm{b}}$ \\
\hline
\end{tabular}


$0.03 \%(\mathrm{w} / \mathrm{v}) \mathrm{FeCl}_{3} 6 \mathrm{H}_{2} \mathrm{O}$ and heated in a water bath for $45 \mathrm{~min}$ followed by centrifugation at $3000 \times g$ for $10 \mathrm{~min}$. The precipitate was recovered and soaked in $20 \mathrm{~mL}$ of $3 \%(\mathrm{w} / \mathrm{v})$ TCA, re-centrifuged at $3000 \times \mathrm{g}$ for $10 \mathrm{~min}$, and rinsed with distilled water. Subsequently, the sample was dispersed in $3.0 \mathrm{~mL}$ of $1.5 \mathrm{M} \mathrm{NaOH}$ and distilled water to $30 \mathrm{~mL}$ final volume and heated for $30 \mathrm{~min}$. The precipitated sample was attained by filtering using a Whatman filter paper (No. 2) and washed with 60 $\mathrm{mL}$ of hot distilled water. The precipitate was dissolved in $40 \mathrm{~mL}$ of hot $3.2 \mathrm{~N} \mathrm{HNO}_{3}$ and made up the volume to $100 \mathrm{~mL}$ with distilled water. $5 \mathrm{~mL}$ of aliquot was diluted with distilled water and $20 \mathrm{~mL}$ of $1.5 \mathrm{M} \mathrm{KSCN}$ to $100 \mathrm{~mL}$. Subsequently, absorbance was measured using a spectrophotometer at $480 \mathrm{~nm}$. The phytic acid contents were calculated based on a standard curve prepared from a stock solution of $433 \mathrm{mg} \mathrm{Fe}\left(\mathrm{NO}_{3}\right)_{3}$ in $100 \mathrm{ml} \mathrm{dH} \mathrm{H}_{2} \mathrm{O}$.

In-vitro protein digestibility by trypsin and pepsin

The in-vitro digestibility rate by trypsin was conducted according to the method of Yin et al. (2008) with modification. The soluble protein sample was diluted with $10 \mathrm{~mm}$ phosphate buffer ( $\mathrm{pH} 8.0$ ) to the final concentration of $2.00 \mathrm{mg} / \mathrm{mL}$. One $\mathrm{mg} / \mathrm{L}$ of trypsin was added to the protein solution, and the mixture was incubated in a water bath at $37^{\circ} \mathrm{C}$. Samples were taken out at every 30 min interval until $120 \mathrm{~min}$. The enzyme reaction was stopped by adding an equal volume of $20 \%$ $(\mathrm{w} / \mathrm{v})$ trichloroacetic acid (TCA). Precipitated protein was removed by centrifugation at $10,000 \times$ $g$ for $20 \mathrm{~min}$.

Meanwhile, the in-vitro digestibility rate by pepsin was conducted according to the modified method by Bamdad et al. (2009) and Mirzakhani et al. (2018). One hundred $\mathrm{mL}$ of protein solution was adjusted to $\mathrm{pH} 2.0$ using $1 \mathrm{~N} \mathrm{HCl}$ and pepsin was added at 250:1 (v/v) substrate: enzyme ratio. The mixture was incubated in a water bath at $37^{\circ} \mathrm{C}$ and samples were taken at every $30 \mathrm{~min}$ interval until $120 \mathrm{~min}$. The reaction was stopped by adding $1.0 \mathrm{M} \mathrm{NaOH}$ until $\mathrm{pH} 5.0$ and boiled in a water bath for $10 \mathrm{~min}$. Subsequently, the protein content was determined using the Bradford method (1976) as previously described. Three replicates were used for each condition.

\section{Statistical analysis}

All data obtained were analyzed using a oneway analysis of variance (ANOVA: SPSS version 16.0) followed with Tukey test for Post Hoc Multiple Comparisons.

\section{RESULTS AND DISCUSSION}

\section{Soluble protein and phytic acid contents}

Results in Table 2 show the soluble protein content from the selected fermentation conditions. The soluble protein content was dependent on the fermentation period and the fermentation conditions (Table 1). The highest soluble protein content for Sample A, B, and C was after 9, 7, and 11 DAI, respectively. Sample $\mathrm{C}$ contained the highest inoculum size (30\%), however, it occupied the longest incubation period although it produced a significantly highest protein content $(p<0.05)$ among the samples. The results suggested that the amylolytic enzymes such as the $\alpha$-amylase, glucoamylase, and $\alpha$-glucosidase might be activated at higher incubation temperature, which ranges from 37 to $40^{\circ} \mathrm{C}$ (Futagami et al., 2015).

Results in Figure 1 clearly show that the fermentation period significantly contributed to

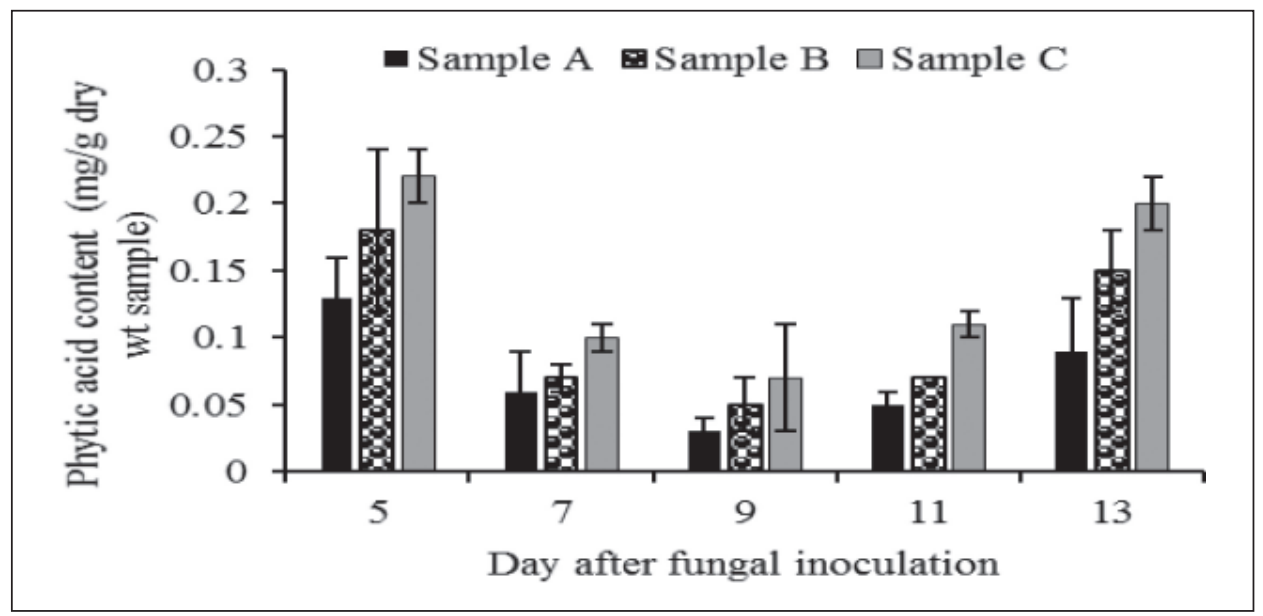

Fig. 1. The phytic acid content in coconut residues from three selected solid-state fermentations at days of fungal inoculation (DAI). Bar indicates the SE, significant difference, $p<0.05$ by Tukey test $(n=3)$. 
the phytic acid content. For all samples, the lowest phytic acid content was determined at 9 DAI, which was in a very low range, from 0.03 to $0.07 \mathrm{mg} / \mathrm{g}$ dry wt. of the sample. However, there is no significant difference $(p>0.05)$ among the treatments at those incubation periods (Figure 1). After that, the phytic acid increased until 13 DAI. The finding showed that the phytic acid and soluble protein ratio is antagonistic. The results suggested that the fermentation process decreased the amount of phytic acid content in the substrate as the fungal growth and development absorbed the nutrients supplied in the medium (Ramachandran et al., 2004). It is considerably proposed that the optimum time for fermentation of coconut residue was at 9 DAI. The divergent connections of both are hypothetically presumed due to microbial phytase produced during fermentation in conjunction with the protein production. Phytic acid might also form a complex with protein (Kies et al., 2006), and is not limited to the cations such as $\mathrm{Ca}, \mathrm{Mg}, \mathrm{K}, \mathrm{Fe}$, or $\mathrm{Zn}$. A previous study showed that 2 to $3 \%$ of soy protein formed were strongly bonded to phytic acid (Rizzo $\&$ Baroni, 2018). The formation of the phytateprotein complex is dependent on the type of protein, $\mathrm{pH}$, the presence of $\mathrm{Ca}$ and $\mathrm{Mg}$, protein solubility rate, proteolytic enzymes, and protein content (Kies et al., 2006). The complex formation may lead to a decreased protein digestibility in farm animals (Cowieson et al., 2006). Phytic acid chelates with minerals in the small intestine at alkaline conditions and forms a poorly soluble complex of phytate (Kemme et al., 1999; Gilani et al., 2005).

In-vitro protein digestibility by trypsin and Pepsin

The main concern in microbial-based derivedprotein is the digestibility of stomach proteases, trypsin, and pepsin. Results of the current study shows that protein digestibility by trypsin on all samples were in the recommended range of digestible protein as desired for aquaculture feed. Generally, fermented coconut residues derived-protein digestibility by both trypsin and pepsin were high after 90 min of incubation for all samples (Figures 2 and 3). Protein digestibility by trypsin for samples A, B, and C were at $43.22 \pm$ $2.46,37.24 \pm 5.62$, and $36.54 \pm 4.22 \%$ after 120 min of digestion, respectively. These rates of protein digestibly were high and fell within the recommended range for fish feed formulation, which is 20 to 45\% (El-Sayed et al., 1999; Abdelnour et al., 2018).

On the other hand, the highest in-vitro protein digestion by pepsin was discovered after $120 \mathrm{~min}$ of incubation (Figure 3) and it was lower compared to trypsin. The highest protein digestibility by pepsin in samples A, B, and C were $19.58 \pm 4.17$, $23.53 \pm 2.92$, and $15.33 \pm 5.5 \%$, respectively. The least protein digestibility might be due to the peptide bond formed among the non-cleavable amino acid by pepsin such as valine and alanine (Mirzakhani et al., 2018). Additionally, the microbial phytase was reported to decrease protein precipitation but increases protein digestibility. The characters of the effective digestibility rate by trypsin and the presence of pepsin-non-cleavable amino acid suggested feed compatibility for animals with a highly efficient digestion system. Nonetheless, the herbivorous fish such as tilapia or catfish with smaller stomach and long intestinal tract as compared to carnivorous fish could permit nutrient efficiency absorption (Farizaldi et al., 2017; Mirzakhani et al., 2018). Also, the fermented coconut residues-derived protein might be suitable

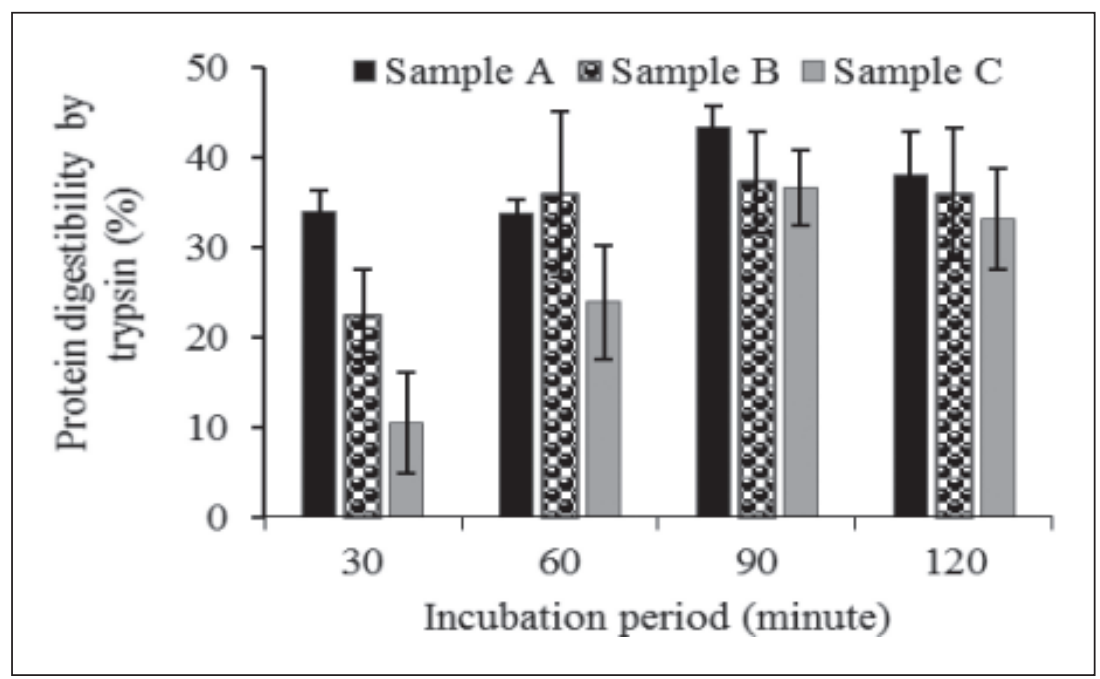

Fig. 2. The protein digestibility by trypsin in coconut residues from three selected solid-state fermentation. Bar indicates the SE, significant difference, $p<0.05$ by Tukey test $(\mathrm{n}=3)$. 


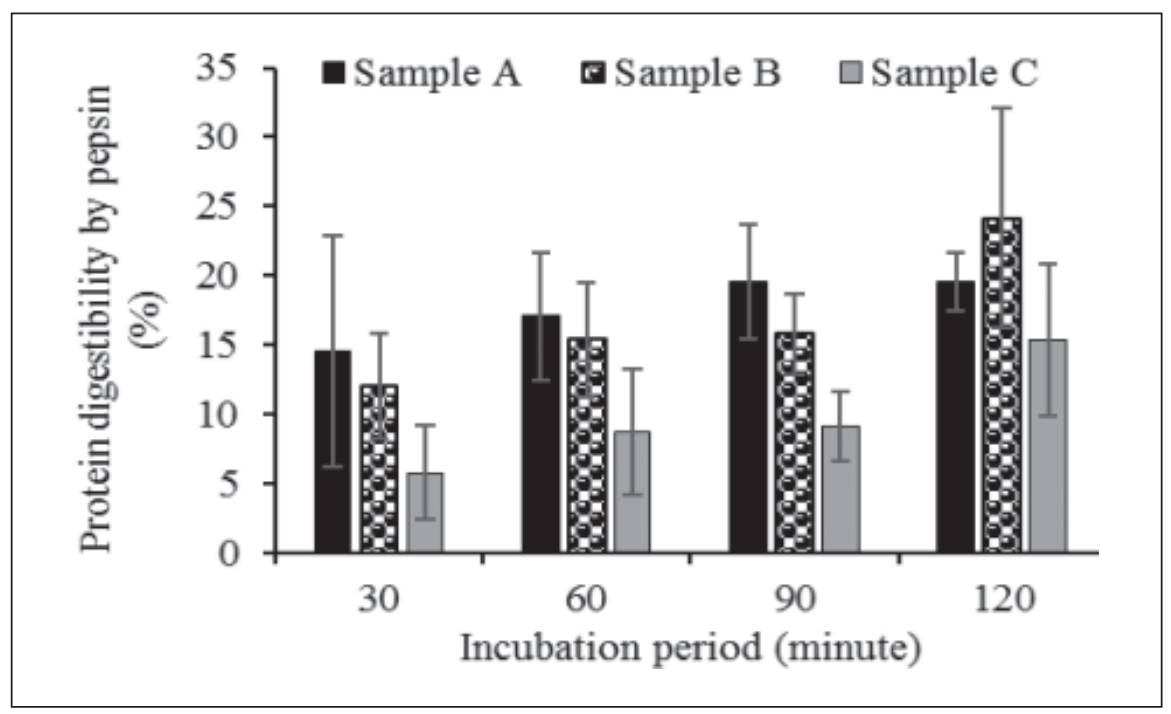

Fig. 3. The protein digestibility by pepsin in coconut residues from three selected solid-state fermentation. Bar indicates the SE, significant difference, $p<0.05$ by Tukey test $(\mathrm{n}=3)$.

for the larvae of Asian sea bass (Lates calcarifer) with the absence of stomach and probably usage of the stomach alkaline protease $(\mathrm{pH} \mathrm{8.0)}$, which not related with pepsin (Ronnestad et al., 2003). Therefore, the ability of $A$. awamori to support the improvement of protein digestibility quality from coconut residue through solid-state fermentation might be the key to a successful increment in processed protein.

\section{CONCLUSION}

The solid-state fermentation of coconut residues by $A$. awamori had increased the soluble protein content with lower phytic acid, the anti-nutritional substance after nine DAI. The amount of soluble protein and phytic acid, together with protein digestibility were influenced by the period of fermentation. The fermented coconut residuesderived protein exhibits high protein digestibility by the intestine enzyme trypsin than the stomach enzyme pepsin. The findings suggested that the derived-protein could be proficient as a feed for herbivorous fishes. This opens to a new insight in bioconversion of agro-waste into wealth, where the fermented coconut residue is a renewable sparing protein and/or energy in feed formulation.

\section{ACKNOWLEDGEMENT}

The authors would like to thank the Ministry of Education Malaysia (Higher Education Department) for funding this research under the Fundamental Research Grant Scheme (FRGS).

\section{REFERENCES}

Abdelnour, S.A., Abd El-Hack, M.E. \& Ragni, M. 2018. The efficacy of high protein tropical forages as alternative protein source for chickens: A review. Agriculture, 8 (86): 1-14.

Bamdad, F., Dokhani, S., Keramat, J. \& Zareie, R. 2009. The impact of germination and in vitro digestion on the formation of angiotensin converting enzyme (ACE) inhibitory peptides from lentil proteins compared to whey proteins. Engineering Technology, 3(1): 36-46.

Bradford, M.M. 1976. A rapid and sensitive method for the quantitation of microgram quantities of protein utilizing the principle of protein dye binding. Analytical Biochemistry, 72: 248-254.

Cowieson, A.J., Acamovic, T. \& Bedford, M.R. 2006. Phytic acid and phytase: implications for protein utilization by poultry. Poultry Science, 85(5): 878-85.

Duy, N.T. \& Khang, D.N. 2016. Effect of coconut (Cocos nucifera) meal on growth and rumen methane production of Sindhi cattle fed cassava (Manihot esculenta, Crantz) pulp and Elephant grass (Pennisetum pupureum). Livestock Research for Rural Development, 28(11): 197.

De Lima, M.R., Ludke, M.C.M.M., de Holanda, M.C.R., Pinto, B.W.C., Ludke, J.V. \& Santos, E.L. 2012. Performance and digestibility of Nile tilapia fed with pineapple residue bran. Acta Scientiarum, 34(1): 41-47.

El-Sayed, A.-F.M. 1999. Alternative dietary protein sources for farmed tilapia, Oreochromis spp. Aquaculture, 179: 149-168. 
Farizaldi, Jamarun, N., Jafrinur \& Marlida, Y. 2017. The effects of fermented coconut waste to the growth of catfish (Clarias sp). International Journal of Agricultural Sciences, 1(1): 21-27.

Futagami, T., Mori, K., Wada, S., Ida, H., Kajiwara, Y., Takashita, H., Tashiro, K., Yamada, O., Omori, T., Kuhara, S. \& Goto, M. 2015. Transcriptomic analysis of temperature responses of Aspergillus kawachii during barley koji production. Applied and Environmental Microbiology, 81: 1353-1363.

Francis, G., Makkar, H.P.S. \& Becker, K. 2001. Antinutritional factors present in plant-derived alternate fish feed ingredients and their effects in fish. Aquaculture, 199: 197-227.

Gaylord, T.G. \& Barrows, F.T. 2009. Multiple amino acid supplementations to reduce dietary protein in plant-based rainbow trout Oncorhynchus mykiss feeds. Aquaculture, 287(1-2): 180-184.

Gilani, G.S., Cockell, K.A. \& Sepehr, E. 2005. Effects of anti-nutritional factors on protein digestibility and amino acid availability in foods. Journal of AOAC International, 88(3): 967-987.

Kies, A.K., De Jonge, L.H., Kemme, P.A. \& Jongbloed, A.W. 2006. Interaction between protein, phytate, and microbial phytase. In vitro studies. Journal of Agricultural and Food Chemistry, 54(5): 1753-1758.

Mamauag, R.E.P., Ragaza, J.A. \& Nacionales, T. 2019. Fish performance, nutrient digestibilities, and hepatic and intestinal morphologies in grouper Epinephelus fuscoguttatus fed fermented copra meal. Aquaculture Reports, 14: 100202.

Mirzakhani, M.K., Kenari, A.A. \& Motamedzadegan, A. 2018. Prediction of apparent protein digestibility by in vitro $\mathrm{pH}$-stat degree of protein hydrolysis with species-specific enzymes for Siberian sturgeon (Acipenser baeri, Brandt 1869). Aquaculture, 496: 73-78.

Moo-Young, M., Xu, J., Wang, L., Ridgway, D. \& $\mathrm{Gu}$, T. 2000. Increased heterologous protein production in Aspergillus niger fermentation through extracellular proteases inhibition by pelleted growth. Biotechnology Progress, 16: 222-227.
Mohd-Razali, A., Taib, M., Murni, M.M. \& Ahmad, A. 2019. Bioconversion of coconut residue to soluble protein by Aspergillus awamori. Malaysian Applied Biology, 48(1): 241-249.

Morgado, H.S., Cysneiros, C.S.S., Sousa, C.M., Stringhini, J.H., Ulhoa, C.J., Silva, A.S., Neto, R.F., Freitas, P.V.D.X., Oliveira, H.P. \& Batista, L.H.C. 2016. Addition of amylase from Aspergillus awamori to the diet of broiler chickens. Brazilian Journal of Poultry Science, 18(4): 725-731.

Pickardt, C., Neidhart, S., Griesbach, C., Dube, M., Knauf, U., Kammerer, D.R. \& Carle, R. 2009. Food hydrocolloids optimisation of mild-acidic protein extraction from defatted sunflower (Helianthus annuus L.) meal. Food Hydrocolloids, 23(7): 1966-1973.

Ramachandran, S., Patel, A.K., Nampoothiri, K.M., Francis, F., Nagy, V., Szakacs, G. \& Pandey, A. 2004. Coconut oil cake - a potential raw material for the production of $\alpha$-amylase. Bioresource Technology, 93: 169-174.

Rizzo, G. \& Baroni, L. 2018. Soy, soy foods and their role in vegetarian diets. Nutrients, 10(1): 43.

Sadasivam, S. \& Manickam, A. 1996. Biochemical Methods. New Age International (P) Limited Publishers, New Delhi.

Saleh, A.A., Gálik, B., Arpášová, H., Capcarová, M., Kalafová, A., Šimko, M., Juráèek, M., Rolinec, M., Bíro, D. \& Abudabos, A.M. 2017. Synergistic effect of feeding Aspergillus awamori and lactic acid bacteria on performance, egg traits, egg yolk cholesterol, and fatty acid profile in laying hens. Italian Journal of Animal Science, 16(1): 132-139.

Syahri, Y.F. 2016. Potency of dregs coconut fermentation (Cocos nucifera) as an alternative feed for fish and poultry 'PA-BIO. Agrotechnology Journal, 1(1): 45-49.

Yin, S., Tang, C., Wen, Q., Yang, X. \& Li, L. 2008. Functional properties and in vitro trypsin digestibility of red kidney bean (Phaseolus vulgaris L.) protein isolate: Effect of highpressure treatment. In vitro, 110: 938-945. 